\title{
The microbiome of the cloacal openings of the urogenital and anal tracts of the tammar wallaby, Macropus eugenii
}

\begin{abstract}
Correspondence
Elizabeth M. Deane

elizabeth.deane@anu.edu.au
\end{abstract}

Received 11 November 2007

Revised 6 January 2008

Accepted 2 March 2008
Kim-Ly Chhour, ${ }^{1,3}$ Lyn A. Hinds, ${ }^{2}$ Elizabeth M. Deane ${ }^{1} \dagger$ and Nicholas A. Jacques ${ }^{3}$

\author{
${ }^{1}$ Department of Biological Sciences, Division of Environmental and Life Sciences, Macquarie \\ University, NSW 2109, Australia \\ ${ }^{2}$ CSIRO Entomology, GPO Box 1700, Canberra, ACT 2601, Australia \\ ${ }^{3}$ Institute of Dental Research, Westmead Millennium Institute and Westmead Center for Oral \\ Health, Westmead, NSW 2145, Australia
}

\begin{abstract}
The bacterial diversity of the openings of the urogenital and anal tracts of the adult female tammar wallaby, Macropus eugenii, was determined in order to ascertain whether the physical proximity of the openings of these tracts within the cloaca affected the two populations of bacteria.

Terminal restriction fragment length polymorphism (T-RFLP) analyses of 42 wallabies identified 81 different terminal fragments, indicative of diverse and complex microbiomes at these anatomical locations. Subsequent amplified rDNA restriction analysis (ARDRA) identified 72 phylotypes from the urogenital tract and 50 from the anal tract. Twenty-two of these phylotypes were common to both tracts. Phylogenetic analysis of sequenced $16 \mathrm{~S}$ rDNA showed that $83 \%$ of the phylotypes were unidentified species based on the premise that any sequence possessing $<97 \%$ homology to a known bacterial species or phylotype was novel. Thus, despite the close proximity of the openings of the urogenital and anal tracts within the cloaca, the two sites retained a diverse range of distinct bacteria, with only a small percentage of overlapping species.
\end{abstract}

\section{INTRODUCTION}

Metatherian (marsupial) mammals offer a unique biological opportunity to investigate the relationship between the microflora of the urogenital and anal tracts. In contrast to eutherian (placental) mammals, which possess separate openings of the digestive and urogenital systems, most marsupials possess a common posterior chamber for these systems - the cloaca (Tyndale-Briscoe, 2005; Fig. 1). This structural feature might imply that bacteria from one tract have easy access to the other. To date, the bacteria associated with these two sites have not been studied in marsupials, although in humans it has been noted that the bacteria of the urogenital tract may vary and can be

†Present address: Australian National University, Canberra, ACT 0200, Australia.

Abbreviations: ARDRA, amplified rDNA restriction analysis; T-RFLP, terminal restriction fragment length polymorphism.

The GenBank/EMBL/DDBJ accession numbers for the DNA sequences of the species or phylotypes identified in this study are EU289036-EU289066 and EU289069-EU289139.

A supplementary table of phylotypes isolated from the urogenital and anal tracts of the tammar wallaby is available with the online version of this paper. influenced by bacteria growing in the anal tract and thus occasionally can cause urogenital disease (Reid et al., 2001; Tannock, 1999).

The tammar wallaby, Macropus eugenii, is regarded as a model marsupial (Tyndale-Briscoe, 2005) with more than 30 years of fundamental research into its basic biology. Despite this, little is known about the bacterial populations of this animal, all published studies having used culture-based methods that are known to be biased in favour of a small percentage of the total microbiome (Hume, 1999; Lentle et al., 2006; Old \& Deane, 1998; Yadav et al., 1972).

In this study we used molecular-based methods targeting the $16 \mathrm{~S}$ rDNA gene to document the bacteria at the openings of the urogenital and anal tracts of 42 female tammar wallabies and undertook a comprehensive comparison of the major phylotypes and their diversity. This is believed to be the first extensive report of the bacterial species within the openings of these two tracts in any marsupial. The results showed that despite the close anatomical proximity of the openings of these tracts, each opening possessed a diverse and complex bacterial population comprising mainly unidentified species. 


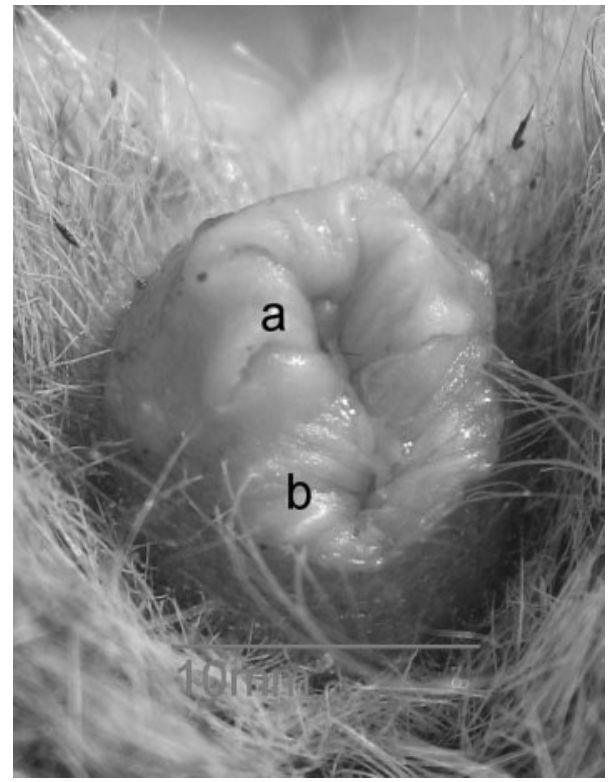

Fig. 1. Photograph of an everted cloaca from a juvenile female tammar wallaby showing the urogenital opening (a) and anal opening (b).

\section{METHODS}

Animals and sample collection. The tammar wallabies used in this study were from two captive breeding populations maintained in large natural enclosures. One colony was located at Macquarie University, Sydney, Australia, and the other was at the CSIRO Sustainable Ecosystems, Canberra, Australia. All research involving animal handling and sample collection was carried out in a manner approved by Macquarie University's Animal Ethics Committee (reference number 2004/015) or the CSIRO Sustainable Ecosystems Animal Ethics Committee (reference number 04-05-26). Sterile cotton-wool-tipped wooden swabs dipped in sterile PBS containing $15 \%(\mathrm{v} /$ v) glycerol were used to collect samples from the openings of the anal and the urogenital tracts of 42 adult female tammar wallabies, 36 of which were carrying pouch young of varying ages (0-60 days). After swabbing, the cotton wool ends of the wooden swabs were broken off into sterile $1.5 \mathrm{ml}$ microfuge tubes containing $300 \mu \mathrm{l}$ sterile PBS with $15 \%$ (v/v) glycerol and kept at $4{ }^{\circ} \mathrm{C}$ until all sampling was completed $(<5 \mathrm{~h})$ and then transferred to a $-80{ }^{\circ} \mathrm{C}$ freezer in the laboratory prior to processing.

DNA extraction. Samples were thawed on ice and vortexed for $2 \mathrm{~min}$ to achieve a homogeneous suspension. A $20 \mu \mathrm{l}$ aliquot of each sample was taken for DNA extraction and mixed with $180 \mu \mathrm{l}$ buffer consisting of $10 \mathrm{mM}$ sodium phosphate $\mathrm{pH} 6.7$ containing $400 \mu \mathrm{g}$ lysozyme (Roche Applied Science), $200 \mathrm{U}$ mutanolysin (Sigma Aldrich) and $400 \mu \mathrm{g}$ proteinase $\mathrm{K}$ (Qiagen), with $20 \mathrm{mM}$ diethyl pyrocarbonate (Sigma Aldrich) and incubated at $56{ }^{\circ} \mathrm{C}$ for $2 \mathrm{~h}$. Bacterial cells were lysed with $1 \%(\mathrm{w} / \mathrm{v})$ SDS and $200 \mu \mathrm{g}$ RNase (Sigma Aldrich) added prior to further incubation at $37{ }^{\circ} \mathrm{C}$ for 10 min (Smith-Vaughan et al., 2006). DNA was subsequently isolated and purified using a QIAamp DNA Mini kit (Qiagen), according to the manufacturer's protocol.

Terminal restriction fragment length polymorphism analysis. Terminal restriction fragment length polymorphism (T-RFLP) analysis (Marsh, 1999) was performed on the 16S rDNA extracted from bacteria present in the urogenital and anal swabs collected from 42 tammar wallabies. Duplicate samples of bacterial $16 \mathrm{~S}$ rRNA genes were amplified by PCR using AmpliTaq Gold with GeneAmp (Applied Biosystems) and the fluorescently labelled $5^{\prime}$-hexachlorofluorescein phosphoramidite (HEX) F27 (HEX-5'-AGAGTTTGATCMTGGCTCAG-3') and the R1492 (5'-TACGGYTACCTTGTTACGACTT- ${ }^{\prime}$ ) primers (Weisburg et al., 1991). The PCR conditions were $94{ }^{\circ} \mathrm{C}$ for $10 \mathrm{~min}$ followed by 35 cycles of amplification at $94{ }^{\circ} \mathrm{C}$ for $30 \mathrm{~s}, 60{ }^{\circ} \mathrm{C}$ for $30 \mathrm{~s}$ and $72{ }^{\circ} \mathrm{C}$ for $90 \mathrm{~s}$. PCR products were digested using RsaI (Promega Life Sciences) for $1 \mathrm{~h}$ and then deactivated at $65{ }^{\circ} \mathrm{C}$ for 15 min prior to T-RFLP analysis being performed on an Applied Biosystems $3130 \times 1$ Genetic Analyzer (Applied Biosystems) at the Macquarie University DNA Sequencing Facility.

Amplified rDNA restriction analysis and sequencing of 165 rRNA genes. Urogenital and anal swabs from two female wallabies carrying a 1- or 4-day-old pouch young were found to generate the highest number of dissimilar terminal fragments following T-RFLP analysis and therefore were used to generate $16 \mathrm{~S}$ rRNA gene libraries. Bacterial 16S rRNA genes were amplified by PCR as described above for T-RFLP analysis except that the forward primer, F27a, did not contain a fluorescent HEX tag and 25 amplification cycles were used. The PCR products were cloned into a T-tailed pGEM vector (Promega Life Sciences), heat shocked into Escherichia coli DH5 $\alpha$ (Invitrogen) and the transformed E. coli grown on Luria-Bertani agar plates prior to 96 colonies being randomly selected from the urogenital and anal tracts of both wallabies to form a clone library. The inserts within the plasmid vectors were recovered by PCR using vector-specific primers $\mathrm{PGEM}-\mathrm{F}$ (5'-GGCGGTCGCGGGAATTCGATT-3') and pGEM-R (5'-GCCGCGAATTCACTAGTGATT-3') (Aislabie et al., 2006) following lysis of the cells in 96 -well plates at $94{ }^{\circ} \mathrm{C}$ for $30 \mathrm{~min}$. The PCR conditions were $94{ }^{\circ} \mathrm{C}$ for 10 min followed by 25 cycles of $94{ }^{\circ} \mathrm{C}$ for $45 \mathrm{~s}, 55{ }^{\circ} \mathrm{C}$ for $45 \mathrm{~s}$ and $72{ }^{\circ} \mathrm{C}$ for $90 \mathrm{~s}$.

Amplified rDNA restriction analyses (ARDRA; Grimont \& Grimont, 1986) of the PCR products made use of the restriction enzymes RsaI and HaeIII to identify unique restriction patterns within the cloned $16 \mathrm{~S}$ rRNA genes. The restriction profiles were manually compared and all unique restriction profiles sequenced. Partial 16S rDNA gene sequences of approximately $1450 \mathrm{bp}$ in length, representing a specific species or phylotype, were sequenced in both directions and compared with known sequences in GenBank (http://www.ncbi.nlm. nih.gov) using the BLAST search tool (Altschul et al., 1997). Since the majority of the phylotypes were novel $(<97 \%$ sequence similarity to any known $16 \mathrm{~S}$ rDNA sequence), they were checked to determine whether they were chimaeras. This was done by first comparing short sections of each sequence to known sequences in the GenBank database as described by Ludwig et al. (1997), and secondly determining the position of each sequence on a phylogenetic tree (see below) with respect to all other phylotypes.

Phylogenetic analysis. The cloned 16S rDNA sequences from the anal and urogenital tracts were aligned using the CLUSTAL $\mathrm{W}$ program (Thompson et al., 1994) accessed through the Australian National Genome Information Service (ANGIS; http://www.angis.org.au/) and neighbourhood joining trees (Saitou \& Nei, 1987) were constructed using the Jukes-Cantor parameter in the MEGA version 4 program (Tamura et al., 2007). Bootstrap analyses of 1000 replicates were used to validate the branch points in the trees.

\section{RESULTS}

\section{T-RFLP analysis and cloning of 16S rDNA}

Duplicate T-RFLP analyses, based on RsaI cleavage of the $16 \mathrm{~S}$ rDNA of the bacteria isolated from 42 female tammar 
wallabies, resulted in 84 T-RFLP population profiles from the urogenital and anal tracts of these animals. Two urogenital and two anal tract samples from two wallabies were found to possess terminal fragments within their TRFLP profiles that together represented 77 of the 81 different terminal fragments identified within the T-RFLP profiles. These four samples were chosen to construct a 192 clone library for each tract. Following ARDRA analysis with RsaI and HaeIII, 105 different clones were identified. After elimination of five chimaeras, the remaining 100 near-full-length $16 \mathrm{~S}$ rDNAs were sequenced. From these sequences, 72 different urogenital and 50 different anal phylotypes were identified (Supplementary Table S1, available with the online version of this article). Twentytwo common phylotypes were found in both tracts (Fig. 2; Supplementary Table S1).

As T-RFLP patterns based only on one restriction enzyme may be insufficient to accurately identify a unique phylotype (Liu et al., 1997; Marsh, 1999; Osborn et al., 2000), in silico terminal fragments from each of the 100 phylotypes were generated and compared with the 81 different terminal fragments observed in the 84 T-RFLP population profiles. This analysis identified 77 of the 81 terminal fragments as unique phylotypes. There were eight in silico phylotypes with no corresponding terminal fragments in the T-RFLP population profiles and four terminal fragments in these profiles with no corresponding in silico phylotype (Table 1).

On closer inspection, some of the phylotypes were found to have the same species identity. For example, clone 8837-D0A-3C, isolated from the anal tract, and clone 8837-D0-C$12 \mathrm{D}$, isolated from the urogenital tract, possessed $100 \%$ and $99 \%$ identity to the $16 \mathrm{~S}$ rRNA of Bacteroides denticanoris. However, this $1 \%$ difference in identity was sufficient for the two sequences to have different terminal fragment sizes of $456 \mathrm{bp}$ and $461 \mathrm{bp}$, respectively (Supplementary Table S1), as well as different HaeIII and RsaI restriction patterns on ARDRA analysis (data not shown).

\section{Phylogenetic and community analysis}

The 100 different $16 \mathrm{~S}$ rDNA sequences comprised five different phyla. These were the Firmicutes, Proteobacteria, Actinobacteria, Fusobacteria and Bacteroidetes; their relative distribution in the two tracts is shown in Fig. 2. As a species is generally accepted to have $\geqslant 97 \%$ homology within the 16S rRNA gene(s) (Stackebrandt \& Goebel, 1994), $83 \%$ of the clones isolated were considered to be novel species as they showed $<97 \%$ homology to any known species currently in GenBank (Supplementary Table S1).

The Firmicutes were the most diverse group; they constituted $54 \%$ of the clones isolated from the urogenital tract and $43.9 \%$ from the anal tract (Table 2). The Firmicutes could be further divided into two classes, the Clostridia and the Lactobacillales, with the Clostridia being the predominant class in both tracts (Table 2). Eight phylotypes from the clostridial class were common to both tracts, with clone 8817-D4-A-7F representing a sizeable proportion $(8.3 \%)$ of the clones isolated from the anal tract, but only $0.6 \%$ of the clones from the urogenital tract (Fig. 2). This phylotype was closely related to Clostridium sp. TO-931 isolated from human faecal samples and found capable of deconjugating bile acids (Wells et al., 2003).

The Lactobacillales constituted $17.2 \%$ of the clones from the urogenital tract and $14.2 \%$ of those from the anal tract. The proportion of phylotypes belonging to the Lactobacillales was $19.2 \%$ and $18 \%$ from the urogenital and anal tracts, respectively, with six common phylotypes in both tracts. The major species in both tracts was Streptococcus dysgalactiae subsp. dysgalactiae (Fig. 2).

The second major phylum was the Bacteroidetes, from the point of view of both the total number of clones isolated and the extent of diversity in both tracts (Table 2). The anal and urogenital tracts shared three common phylotypes, with clone $8817-\mathrm{D} 4-\mathrm{C}-1 \mathrm{~B}$ being the most predominant, representing $17.8 \%$ of the clones isolated from the urogenital tract and $21.5 \%$ from the anal tract (Fig. 2).

The Actinobacteria and Proteobacteria phyla were represented by a similar number of clones irrespective of the tract from which they were isolated (Table 2). Three phylotypes belonging to Actinobacteria were found in both tracts, with Arcanobacterium hippocoleae consituting 10.4\% of the clones isolated from the urogenital tract and 3.4\% from the anal tract (Fig. 2). There were also two phylotypes belonging to the Proteobacteria that were found in both tracts, with Campylobacter helveticus (corresponding to clone 8817-D4-A-1C) being isolated in high numbers only from the anal tract (Fig. 2).

In contrast to the other phyla of bacteria, the Fusobacteria were only detected in the urogenital tract of the two wallabies used as the source of bacteria for ARDRA analysis, and then only at low frequency and diversity since the phylum was represented by only one clone from each of the genera Fusobacterium (clone 8817-D4-C-10F) and Leptotrichia (clone 8837-D0-C-11B; Fig. 2; Table 1). TRFLP analysis of the 42 tammar wallabies, however, showed that these two phylotypes could potentially be isolated from both the urogenital and the anal openings within the cloaca. Clone 8817-D4-C-10F was isolated from $23.9 \%$ of both openings while clone $8837-\mathrm{D} 0-\mathrm{C}-11 \mathrm{~B}$ was isolated from $76.2 \%$ of the urogenital and $57.1 \%$ of the anal openings, respectively.

\section{DISCUSSION}

As the identified phylotypes were based on the original TRFLP analyses of 42 female wallabies, they represent a compilation of the major bacteria found in the two anatomical openings of the cloaca of the tammar wallaby. The results contrast strongly with previous cultivationbased studies, which suggested that there was little diversity 


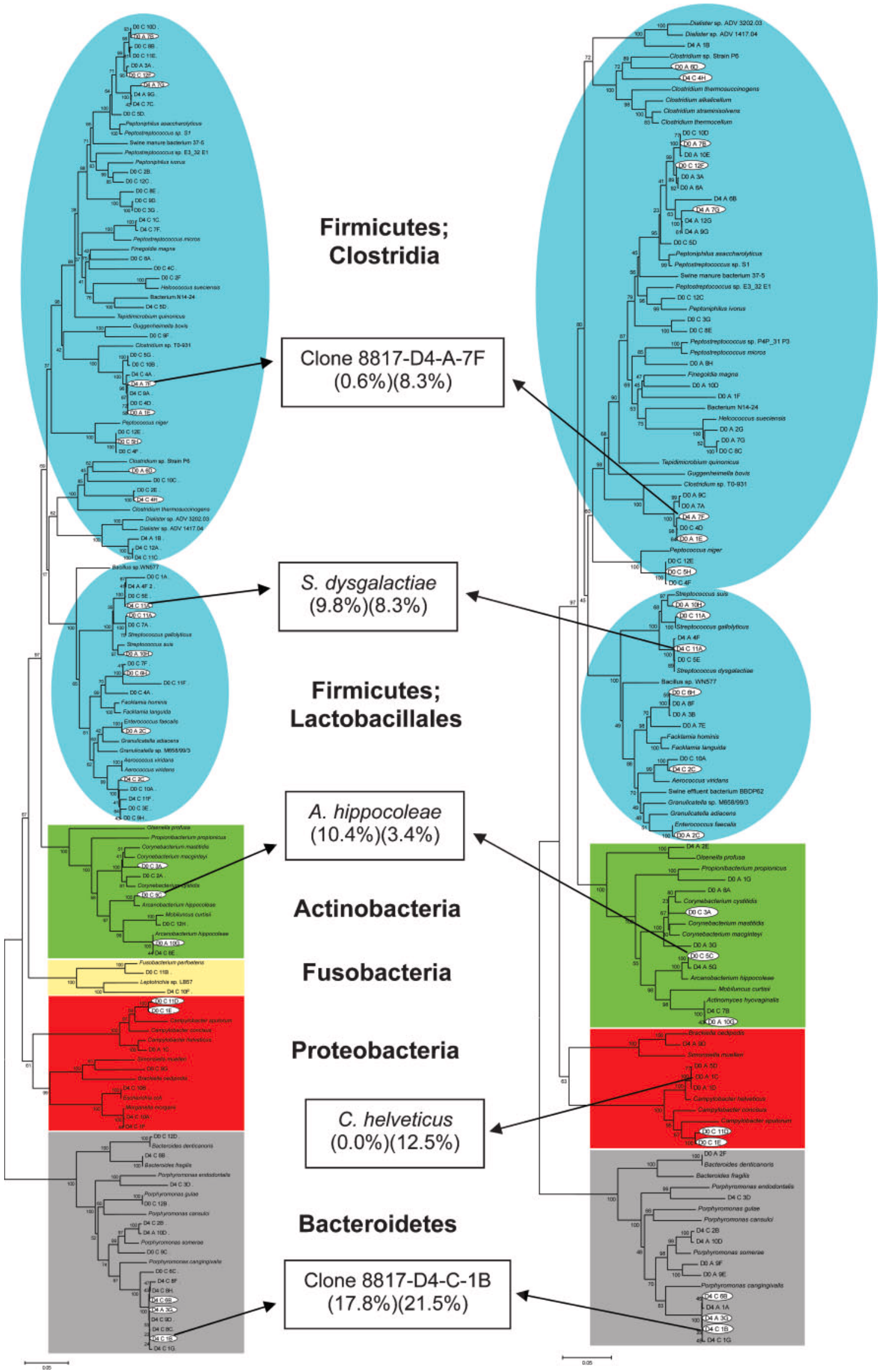


Fig. 2. Phylogenetic trees constructed from near-full-length (1442 bp) $16 \mathrm{~S}$ rDNA sequences obtained from randomly cloned genes of bacteria isolated from the openings of the urogenital tract (left) and anal tract (right) of the tammar wallaby. Both trees were constructed with maximum-likelihood using the Jukes-Cantor parameter. The trees were bootstrapped 1000 times, and bootstrap values are shown at the branch points. Each phylum is defined by a different colour, with phylotypes common to both tracts highlighted in white ovals. The five most predominant phylotypes from the urogenital tract and the anal tract are highlighted, with the percentage of clones isolated from each site, respectively, shown in parentheses between the two trees. Where a phylotype possessed $\geqslant 97 \%$ identity to a known species, the phylotype was given the species name, otherwise the clone name was used.

within the microbiome of marsupials at these sites (Hume, 1999; Lentle et al., 2006; Yadav et al., 1972). For example, only 15 different bacterial colony types were observed in the stomach of the quokka, Setonix brachyurus (Moir et al., 1956), while direct visualization of smears from the vaginal cul-de-sac of the brushtail possum, Trichosurus vulpecula, detected only rod and coccal morphological types (Mahoney et al., 2002). Furthermore, culture-based studies of the forestomach of the eastern grey kangaroo, Macropus giganteus, resulted in the identification of only 17 anaerobic bacterial species, all from the phylum Firmicutes, of which five were known species (Ouwerkerk et al., 2005). More pertinently, Lentle et al. (2006) recently found fewer than five bacterial species in the gut of the tammar wallaby pouch young. Unfortunately, the conclusions drawn from these culture-based studies are known to be biased, since such methods selectively isolate $\leqslant 1 \%$ of the actual bacterial species present (Hugenholtz et al., 1998).

Analysis of the 100 sequenced phylotypes in the current study showed that 83 were novel, based on the premise that their $16 \mathrm{~S}$ rDNAs showed $<97 \%$ sequence identity to known species or phylotypes. Most of the phylotypes belonged to two phyla, the Firmicutes and the Bacteroidetes, irrespective of the anatomical site from where they were isolated. This is consistent with the situation in humans, pigs and mice, where members of the phyla Firmicutes and the Bacteroidetes are also the two largest populations found in the distal gut (Tom-Petersen et al., 2003; Xu et al., 2007). In the tammar wallaby, the two classes of Firmicutes, the Clostridia and the Lactobacillales, represented the largest bacterial populations within the openings of the urogenital and anal tracts, from the point of view of both diversity of phylotypes and the number of clones isolated, a finding that might explain the observations of Ouwerkerk et al. (2005), who cultured only Firmicutes from the forestomach of an eastern grey kangaroo.

Among the class Lactobacillales was a predominant phylotype represented by clone $8817-D 4-C-11$ A (Fig. 2), the 16S-rDNA of which possessed $100 \%$ sequence identity to a $S$. dysgalactiae subsp. dysgalactiae strain isolated from swine (unpublished; GenBank Accession no. AB002504). Strains of this subspecies are known to be major pathogens in bovine mastitis (Denamiel et al., 2005; Park et al., 2002) and they have also recently been reported to cause bacteraemia in puppies (Vela et al., 2006). The closely related bacterium, S. dysgalactiae subsp. equisimilis (99.8\%
16S rDNA sequence identity), is also pathogenic in animals. This bacterium accounts for $5-8 \%$ of human streptococcal wound infections as well as causing toxic shock syndrome following misuse of tampons during menstruation (Horii et al., 2006; Sachse et al., 2002). As only certain strains of the two subspecies of $S$. dysgalactiae are pathogenic in placental mammals (Holt et al., 1994), and as the tammar wallabies used in this study were all considered to be in good health despite the presence and colonization of their urogenital tracts with this bacterium, this may imply that this particular wallaby strain was not virulent, though this would require confirmation.

Surprisingly, no lactobacilli were detected in the opening of either the urogenital or the anal tract. This is in direct contrast to placental mammals, where lactobacilli are readily isolated from both tracts. Moreover, lactobacilli are predominant members of the resident urogenital microflora of healthy adult human females (Reid, 2000). Our observations, however, do not preclude lactobacilli being present in the urogenital tract of the tammar wallaby, as the chance of detecting a cloned $16 \mathrm{~S}$ rDNA with $95 \%$ confidence using a sample size of 96 (as was the case in this study) requires a species to be present at a level $\geqslant 3 \%$ of the population (Chhour et al., 2005). The observation simply means that lactobacilli are not the predominant bacteria found in the urogenital tract of the female wallaby. However, as metatherian and eutherian mammals diverged from a common ancestor approximately 130 million years ago (Marshall Graves \& Westerman, 2002), it is not surprising that the bacteria found in the urogenital tract of the tammar wallaby are different from those found in humans or other placental mammals. Provided a bacterial population contains the appropriate complement of genes for survival in a particular habitat, that population will proliferate independently of the presence of a particular species (Xu et al., 2007). Thus, while the bacteria found in the urogenital tract of the tammar wallaby may be different from those of placental mammals, the various roles they play and the complement of genes they possess may be similar to those of eutherian mammals. In support of this hypothesis is the recent recognition that the greatest impact on the diversity of symbiotic bacteria within different hosts is the nature of the host itself, as up to $70 \%$ of the bacterial diversity at the species level is unique to a given host (Ley et al., 2006).

Next to the Firmicutes, members of the Bacteroidetes were the second most abundant phylum found in the openings to the urogenital and anal tracts of the tammar wallaby. 
Table 1. Phylotype or species corresponding to the terminal fragment length of cloned $16 \mathrm{~S}$ rDNA from tammar wallabies following T-RFLP analysis with Rsal

\begin{tabular}{|c|c|c|c|}
\hline \multirow[t]{2}{*}{$\begin{array}{l}\text { T-RFLP terminal } \\
\text { fragment size }(b p)\end{array}$} & \multicolumn{2}{|c|}{$\begin{array}{l}\text { Percentage of female wallabies }(n=42) \\
\text { possessing bacteria with a given ter- } \\
\text { minal fragment size }\end{array}$} & \multirow[t]{2}{*}{ Corresponding species or phylotype $(s) \dagger$} \\
\hline & Urogenital tract & Anal tract & \\
\hline 33 & - & - & Morganella morganii \\
\hline 65 & - & - & Bacteroides fragilis \\
\hline 70 & - & - & $8837-\mathrm{D} 0-\mathrm{C}-9 \mathrm{H}$ \\
\hline 71 & - & - & $8837-\mathrm{D} 0-\mathrm{A}-6 \mathrm{D}$ \\
\hline 76 & - & - & 8837-D0-A-1G, 8837-D0-A-9E \\
\hline 77 & - & - & $8817-\mathrm{D} 4-\mathrm{C}-4 \mathrm{H}$ \\
\hline 78 & - & - & $8837-\mathrm{D} 0-\mathrm{C}-2 \mathrm{E}$ \\
\hline 80 & - & - & 8837-D0-C-3A, 8817-D4-A-5G \\
\hline 81 & - & - & $8837-\mathrm{D} 0-\mathrm{A}-10 \mathrm{E}$ \\
\hline 89 & - & - & 8817-D4-C-12D \\
\hline 114 & - & - & 8837-D0-C-11D \\
\hline 115 & - & - & Streptococcus gallolyticus \\
\hline 118 & - & - & $8837-\mathrm{D} 0-\mathrm{C}-11 \mathrm{E}$ \\
\hline 119 & - & - & 8817-D4-A-4H \\
\hline 126 & 0.0 & 50.0 & $8837-\mathrm{D} 0-\mathrm{A}-8 \mathrm{~A}$ \\
\hline 129 & 73.8 & 0.0 & $8837-\mathrm{D} 0-\mathrm{C}-2 \mathrm{~A}$ \\
\hline 142 & 83.0 & 81.0 & 8837-D0-C-9D \\
\hline 155 & & & 8837-D0-C-10B $\ddagger$ \\
\hline 157 & & & 8837-D0-A-7A $\ddagger$ \\
\hline 160 & & & $8837-\mathrm{D} 0-\mathrm{C}-5 \mathrm{G} \ddagger$ \\
\hline $170-173 \$$ & 52.4 & 40.5 & 8817-D4-C-11D, 8817-D4-C-4A, 8817-D4-C-12A \\
\hline $174-175 \$$ & 37.1 & 52.4 & 8817-D4-A-1F, 8817-D4-A-1B \\
\hline 181 & 0.0 & 2.4 & $8837-\mathrm{D} 0-\mathrm{A}-1 \mathrm{E}$ \\
\hline 193 & 19.0 & 14.3 & 8837-D0-A-8H \\
\hline 242 & & & 8817-D4-C-9A $\ddagger$ \\
\hline 251 & 0.0 & 2.4 & $8837-\mathrm{D} 0-\mathrm{A}-9 \mathrm{C}$ \\
\hline $276-278 \$$ & 9.5 & 0.0 & 8817-D4-C-7D, 8817-D4-A-2E \\
\hline 279 & 0.0 & 14.3 & $8837-\mathrm{D} 0-\mathrm{A}-3 \mathrm{G}$ \\
\hline 310 & 0.0 & 7.1 & Not found \\
\hline 321 & 4.7 & 9.5 & Porphyromonas gulae \\
\hline 414 & & & $8837-\mathrm{D} 0-\mathrm{A}-2 \mathrm{G} \ddagger$ \\
\hline $422-424 \$$ & 4.7 & 16.7 & Morganella morganii, Escherichia coli \\
\hline 430 & 4.7 & 4.7 & Not found \\
\hline 434 & 52.4 & 47.6 & 8837-D0-A-7E \\
\hline 440 & 16.7 & 11.9 & 8837-D0-C-11G \\
\hline 443 & 23.9 & 23.9 & 8817-D4-C-10F \\
\hline 453 & 23.9 & 45.2 & $8837-\mathrm{D} 0-\mathrm{C}-9 \mathrm{C}$ \\
\hline $454-456 \$$ & 76.2 & 57.1 & $\begin{array}{l}\text { Campylobacter helveticus, Uncultured Bacterium clone J2-29, Bacteroides } \\
\text { denticanoris, 8837-D0-C-1E, 8817-D4-C-2B }\end{array}$ \\
\hline $460-461 \S$ & 78.6 & 52.4 & 8817-D4-C-10D, Bacteroides denticanoris \\
\hline $463-464 \$$ & 50.0 & 61.9 & $\begin{array}{l}\text { 8837-D0-C-4C, 8837-D0-C-12F, C. helveticus, 8817-D4-C-7C, 8817-D4-C- } \\
\text { 9G, 8817-D4-A-6B, 8837-D0-A-1F, 8817-D4-A-12G }\end{array}$ \\
\hline $465-466 \$$ & 50.0 & 61.9 & $8837-\mathrm{D} 0-\mathrm{A}-7 \mathrm{~B}, 8837-\mathrm{D} 0-\mathrm{A}-6 \mathrm{~A}$ \\
\hline $467-468 \$$ & 52.4 & 37.1 & $\begin{array}{l}\text { 8837-D0-C-8B, 8817-D4-C-1H, 8837-D0-C-2B, 8837-D0-C-10C, 8837-D0- } \\
\text { C-9F }\end{array}$ \\
\hline $475-476 \$$ & 11.9 & 11.9 & 8817-D4-C-8F, 8817-D4-C-9D, 8817-D4-C-8C \\
\hline $479-481 \S$ & 47.6 & 59.5 & $\begin{array}{l}\text { 8817-D4-C-8H, 8817-D4-A-3G, 8817-D4-A-1A, 8817-D4-C-6B, 8817-D4-C- } \\
\text { 1B }\end{array}$ \\
\hline 483 & & & 8817-D4-A-9D $\ddagger$ \\
\hline 493 & 9.5 & 0.0 & 8817-D4-C-11C \\
\hline 500 & 28.6 & 45.2 & Not found \\
\hline 550 & & & 8837-D0-A-10D $\ddagger$ \\
\hline
\end{tabular}


Table 1. cont.

\begin{tabular}{|c|c|c|c|}
\hline \multirow[t]{2}{*}{$\begin{array}{l}\text { T-RFLP terminal } \\
\text { fragment size }(b p)\end{array}$} & \multicolumn{2}{|c|}{$\begin{array}{l}\text { Percentage of female wallabies }(n=42) \\
\text { possessing bacteria with a given ter- } \\
\text { minal fragment size }\end{array}$} & \multirow[t]{2}{*}{ Corresponding species or phylotype $(s) \dagger$} \\
\hline & Urogenital tract & Anal tract & \\
\hline $556-563 \S$ & 83.0 & 69.0 & $\begin{array}{l}\text { 8837-D0-C-2F, 8837-D0-A-7G, 8837-D0-C-8A, 8817-D4-C-1C, 8837-D0-C- } \\
\text { 7F, 8817-D4-C-7F }\end{array}$ \\
\hline 571 & & & Streptococcus dysgalactiae $\ddagger$ \\
\hline $618-623 \S$ & 2.4 & 0.0 & Mobiluncus curtisii, Actinomyces hyovaginalis \\
\hline 628 & 11.9 & 38.1 & Actinomyces hyovaginalis/Streptococcus dysgalactiae \\
\hline 631 & 14.3 & 7.1 & Streptococcus suis \\
\hline 653 & 9.5 & 7.1 & $8817-\mathrm{D} 4-\mathrm{C}-2 \mathrm{C}$ \\
\hline $657-660 \$$ & 21.4 & 31.0 & $8817-\mathrm{D} 4-\mathrm{C}-11 \mathrm{~F}, 8837-\mathrm{D} 0-\mathrm{C}-3 \mathrm{E}$ \\
\hline $733-736 \$$ & 37.1 & 40.5 & 8817-D4-C-3D, 8837-D0-A-9F \\
\hline 743 & & & 8817-D4-C-5D \\
\hline 840 & 9.5 & 0.0 & 8837-D0-C-2D \\
\hline 844 & 0.0 & 7.1 & $8837-\mathrm{D} 0-\mathrm{C}-5 \mathrm{H}$ \\
\hline 860 & 11.9 & 28.6 & Not found \\
\hline 867 & 45.3 & 61.9 & $8837-\mathrm{D} 0-\mathrm{A}-3 \mathrm{~B}$ \\
\hline 883 & 19.0 & 38.1 & 8837-D0-C-6H/8837-D0-C-9G \\
\hline 886 & 50.0 & 37.1 & Streptococcus gallolyticus \\
\hline 889 & 38.1 & 42.9 & Streptococcus gallolyticus \\
\hline 893 & 50.0 & 40.5 & 8837-D0-A-8F \\
\hline 899 & 31.0 & 45.2 & Enterococcus faecalis \\
\hline
\end{tabular}

${ }^{*}$-, 16S rDNA with terminal fragment lengths that could not be accurately determined by T-RFLP analysis due to high background noise. The corresponding phylotypes may be present in the urogenital and anal tracts of a number of tammar wallabies, but the exact percentage could not be accurately determined.

†Where subsequent sequencing of a phylotype led to $\geqslant 97 \% 16 \mathrm{~S}$ rDNA identity to a known species, the species name is quoted. Where more than one species/phylotype is listed, each species/phylotype possessed the same terminal fragment size following restriction digestion of $16 \mathrm{~S}$ rDNA with RsaI. 'Not found' indicates that no matching phylotypes were subsequently isolated despite the terminal fragment being identified in the original TRFLP analysis. These phylotypes statistically represent $\leqslant 3 \%$ of the total population in any given wallaby (see text).

$\$$ Phylotypes with no matching terminal fragments in the original T-RFLP analysis.

$\S$ Terminal fragment sizes that could not be separated in the T-RFLP analysis.

Among the porphyromonads belonging to this phylum, $79.3 \%$ of the clones were phylogenetically related to Porphyromonas cangingivalis, originally isolated from the subgingival plaque of dogs (Collins et al., 1994). Although most known porphyromonads are regarded as oral pathogens (Dommisch et al., 2007; Holt et al., 1994), the porphyromonads found in the microbiome of the tammar wallaby could possibly play a different role as they possess $\leqslant 91 \%$ sequence identity to the $16 \mathrm{~S} \mathrm{rDNA}$ to $P$. cangingivalis (Supplementary Table S1). In humans, the genus Bacteroides accounts for approximately $25 \%$ of the bacterial population of the gastrointestinal tract (Xu et al., 2004), with Bacteroides thetaiotaomicron being regarded as a potential probiotic due to its role in regulating glycan metabolism (Xu et al., 2004).

Clone 8837-D0-C-5C represented a phylotype that was also consistently isolated from the openings of the urogenital and anal tracts (Fig. 2; Supplementary Table S1). Its $16 \mathrm{~S}$ rDNA sequence possessed $97 \%$ identity to Arcanobacterium hippocoleae isolated from a horse with vaginitis (Hoyles et al., 2002). To our knowledge, there are only six validated species within the genus Arcanobacterium (Ohba et al., 2007). Members of this genus have been isolated from both animal and human sources (Collins et al., 1982) and include the known pathogens Arcanobacterium pyogenes and Arcanobacterium haemolyticum, and the putative opportunistic pathogen Arcanobacterium bernardiae (Billington \& Jost, 2006; Funke et al., 1995). Other species within the genus, such as Arcanobacterium phocae, are of unknown pathological significance (Hoyles et al., 2002).

In the phylum Proteobacteria, the most readily isolated phylotype was represented by clone $8837-\mathrm{D} 0-\mathrm{A}-1 \mathrm{C}$, which possesses $98 \%$ 16S rDNA identity to Campylobacter helveticus (Fig. 2; Supplementary Table S1). This phylotype was isolated only from the anal tract of the tammar wallaby. Species within the genus Campylobacter, such as Campylobacter coli and Campylobacter jejuni, are important pathogens in humans and animals (Gorkiewicz et al., 2003). However, to the best of our knowledge, C. helveticus, which 
Table 2. Total number of clones analysed by ARDRA and the corresponding proportion of unique phylotypes belonging to each phylum that were detected at the openings of the urogenital and anal tracts of the tammar wallaby

\begin{tabular}{|lccccc|}
\hline \multirow{2}{*}{ Bacterial phylum (class) } & \multicolumn{2}{c}{ ARDRA clones $(\%)^{*}$} & & \multicolumn{2}{c|}{ No. of phylotypes (\%) $\dagger$} \\
\cline { 2 - 3 } \cline { 5 - 6 } & Urogenital & Anal & & Urogenital & Anal \\
\hline Firmicutes (Clostridia) & 36.8 & 29.7 & & 42.5 & 42.0 \\
Firmicutes (Lactobacillales) & 17.2 & 14.2 & & 19.2 & 18.0 \\
Bacteroidetes & 26.4 & 29.7 & & 17.8 & 14.0 \\
Actinobacteria & 12.3 & 10.8 & & 9.6 & 16.0 \\
Proteobacteria & 6.1 & 15.5 & & 8.2 & 14.0 \\
Fusobacteria & 1.2 & ND & & 2.3 & ND \\
\hline
\end{tabular}

ND, not detected.

${ }^{\star}$ The total number of ARDRA clones that were isolated was 162 from the urogenital tract and 148 from the anal tract.

$\dagger$ The number of different phylotypes within the bacterial population was 72 in the urogenital tract and 50 in the anal tract.

was originally isolated from cat and dog faeces (Stanley et al., 1992), is not classified as a pathogen (Mandrell et al., 2005). C. helveticus is closely related to Campylobacter upsaliensis, which, although being associated with human diseases such as abscess, gastroenteritis and bacteraemia, has an ill-defined mode of pathogenicity (Moser et al., 2001).

In conclusion, the current molecular phylogenetic study showed that the bacterial populations found in the openings of the urogenital and anal tracts of the tammar wallaby are far more diverse and complex than previously reported for other anatomical sites in marsupials using simple culturing techniques. Although most of the bacteria represent potentially novel species, the majority belong to two predominant phyla, the Firmicutes and the Bacteroidetes, in a similar manner to that documented for placental mammals.

\section{ACKNOWLEDGEMENTS}

K.-L.C. was the recipient of a RAACE Postgraduate Scholarship awarded by Macquarie University.

\section{REFERENCES}

Aislabie, J. M., Chhour, K.-L., Saul, D. J., Miyauchi, S., Ayton, J., Paetzold, R. F. \& Balks, M. R. (2006). Dominant bacteria in soils of Marble Point and Wright Valley, Victoria Land, Antarctica. Soil Biol Biochem 38, 3041-3056.

Altschul, S. F., Madden, T. L., Schaffer, A. A., Zhang, J., Zhang, Z., Miller, W. \& Lipman, D. J. (1997). Gapped BLAST and PSI-BLAST: a new generation of protein database search programs. Nucleic Acids Res 25, 3389-3402.

Billington, S. J. \& Jost, B. H. (2006). Multiple genetic elements carry the tetracycline resistance gene $\operatorname{tet}(\mathrm{W})$ in the animal pathogen Arcanobacterium pyogenes. Antimicrob Agents Chemother 50, 3580-3587.

Chhour, K.-L., Nadkarni, M., Byun, R., Martin, F. E., Jacques, N. A. \& Hunter, N. (2005). Molecular analysis of microbial diversity in advanced caries. J Clin Microbiol 43, 843-849.
Collins, M. D., Jones, D. \& Schofield, G. M. (1982). Reclassification of 'Corynebacterium haemolyticum' (MacLean, Liebow \& Rosenberg) in the genus Arcanobacterium gen. nov. as Arcanobacterium haemolyticum nom. rev., comb. nov. J Gen Microbiol 128, 1279-1281.

Collins, M. D., Love, D. N., Karjalainen, J., Kanervo, A., Forsblom, B., Willems, A., Stubbs, S., Sarkiala, E., Bailey, G. D. \& Wigney, D. I. (1994). Phylogenetic analysis of members of the genus Porphyromonas and description of Porphyromonas cangingivalis sp. nov. and Porphyromonas cansulci sp. nov. Int J Syst Bacteriol 44, 674-679.

Denamiel, G., Llorente, P., Carabella, M., Rebuelto, M. \& Gentilini, E. (2005). Anti-microbial susceptibility of Streptococcus spp. isolated from bovine mastitis in Argentina. J Vet Med B Infect Dis Vet Public Health 52, 125-128.

Dommisch, H., Chung, W. O., Rohani, M. G., Williams, D., Rangarajan, M., Curtis, M. A. \& Dale, B. A. (2007). Protease-activated receptor 2 mediates human beta-defensin 2 and CC chemokine ligand 20 mRNA expression in response to proteases secreted by Porphyromonas gingivalis. Infect Immun 75, 4326-4333.

Funke, G., Ramos, C. P., Fernandez-Garayzabal, J., Weiss, N. \& Collins, M. D. (1995). Description of human-derived Centers for Disease Control coryneform group 2 bacteria as Actinomyces bernardiae sp. nov. Int J Syst Bacteriol 45, 57-60.

Gorkiewicz, G., Feierl, G., Schober, C., Dieber, F., Köfer, J., Zechner, R. \& Zechner, E. L. (2003). Species-specific identification of campylobacters by partial $16 \mathrm{~S}$ rRNA gene sequencing. J Clin Microbiol 41, 2537-2546.

Grimont, F. \& Grimont, P. A. (1986). Ribosomal ribonucleic acid gene restriction patterns as potential taxonomic tools. Ann Inst Pasteur Microbiol 137B, 165-175.

Holt, J. G., Krieg, N. R., Sneath, P. H. A., Staley, J. T. \& Williams, S. T. (editors) (1994). Bergey's Manual of Determinative Bacteriology, 9th edn. Baltimore: Williams \& Wilkins.

Horii, T., Izumida, S., Takeuchi, K., Tada, T., Ishikawa, J. \& Tsuboi, K. (2006). Acute peritonitis and salpingitis associated with streptococcal toxic shock syndrome caused by Lancefield group $\mathrm{G} \alpha$-haemolytic Streptococcus dysgalactiae subsp. equisimilis. J Med Microbiol 55, 953-956.

Hoyles, L., Falsen, E., Foster, G., Rogerson, F. \& Collins, M. D. (2002). Arcanobacterium hippocoleae sp. nov., from the vagina of a horse. Int J Syst Evol Microbiol 52, 617-619. 
Hugenholtz, P., Pitulle, C., Hershberger, K. L. \& Pace, N. R. (1998). Novel division level bacterial diversity in a Yellowstone hot spring. J Bacteriol 180, 366-376.

Hume, I. D. (1999). Marsupial Nutrition. Cambridge: Cambridge University Press.

Lentle, R. G., Dey, D., Hulls, C., Mellor, D. J., Moughan, P. J., Stafford, K. J. \& Nicholas, K. (2006). A quantitative study of the morphological development and bacterial colonisation of the gut of the tammar wallaby Macropus eugenii and in-pouch development. J Comp Physiol [B] 176, 763-774.

Ley, R. E., Turnbaugh, P. J., Klein, S. \& Gordan, J. I. (2006). Human gut microbes associated with obesity. Nature 444, 1022-1023.

Liu, W. T., Marsh, T. L., Cheng, H. \& Forney, L. J. (1997). Characterisation of microbial diversity by determining terminal restriction fragment length polymorphism of genes encoding $16 \mathrm{~S}$ rRNA. Appl Environ Microbiol 63, 4516-4522.

Ludwig, W., Bauer, S. H., Bauer, M., Held, I., Kirchhof, G., Schulze, R., Huber, I., Spring, S., Hartmann, A. \& Schleifer, K. H. (1997). Detection and in situ identification of representatives of a widely distributed new bacterial phylum. FEMS Microbiol Lett 153, 181-190.

Mahoney, P. M., Hurst, P. R., McLeod, B. J. \& McConnell, M. A. (2002). Quantification of mast cells and microflora in the vaginal cul-de-sac of the brushtail possum (Trichosurus vulpecula). Reproduction 124, 399-408.

Mandrell, R. E., Harden, L. A., Bates, A., Miller, W. G., Haddon, W. F. \& Fagerquist, C. K. (2005). Speciation of Campylobacter coli, C. jejuni, C. helveticus, C. lari, C. sputorum, and C. upsaliensis by matrix-assisted laser desorption ionization-time of flight mass spectrometry. Appl Environ Microbiol 71, 6292-6301.

Marsh, T. L. (1999). Terminal restricton fragment length polymorphism (T-RFLP): an emerging method for characterizing diversity among homologous populations of amplification products. Curr Opin Microbiol 2, 323-327.

Marshall Graves, J. A. \& Westerman, M. (2002). Marsupial genetics and genomics. Trends Genet 18, 517-521.

Moir, R. J., Somers, M. \& Waring, H. (1956). Studies on marsupial nutrition I. Ruminant-like digestion in a herbivorous marsupial Setonix brachyurus (Quoy and Gaimard). Aust J Biol Sci 9, 293-304.

Moser, I., Rieksneuwöhner, B., Lentzsch, P., Schwerk, P. \& Wieler, L. H. (2001). Genomic heterogeneity and O-antigenic diversity of Campylobacter upsaliensis and Campylobacter helveticus strains isolated from dogs and cats in Germany. J Clin Microbiol 39, 2548-2557.

Ohba, T., Shibahara, T., Kobayashi, H., Kubo, M., Takashima, A., Imai, S., Murakami, S. \& Kadota, K. (2007). Hemorrhagic necrotizing splenitis in a slaughter pig infected with Arcanobacterium species. J Vet Med Sci 69, 449-453.

Old, J. M. \& Deane, E. M. (1998). The effect of oestrus and the presence of pouch young on aerobic bacteria isolated from the pouch of the tammar wallaby, Macropus eugenii. Comp Immunol Microbiol Infect Dis 21, 237-245.

Osborn, A. M., Moore, E. R. B. \& Timmis, K. N. (2000). An evaluation of terminal-restriction fragment length polymorphism (T-RFLP) analysis for the study of microbial community structure and dynamics. Environ Microbiol 2, 39-50.

Ouwerkerk, D., Klieve, A. V., Forster, R. J., Templeton, J. M. \& Maguire, A. J. (2005). Characterization of culturable anaerobic bacteria from the forestomach of an eastern grey kangaroo, Macropus giganteus. Lett Appl Microbiol 41, 327-333.

Park, H.-M., Almeida, R. A., Luther, D. A. \& Oliver, S. P. (2002). Binding of bovine lactoferrin to Streptococcus dysgalactiae subsp. dysgalactiae isolated from cows with mastitis. FEMS Microbiol Lett 208, 35-39.
Reid, G. (2000). In vitro testing of Lactobacillus acidophilus $\mathrm{NCFM}^{\mathrm{TM}}$ as a possible probiotic for the urogenital tract. Int Dairy J 10, 415-419.

Reid, G., Howard, J. \& Gan, B. S. (2001). Can bacterial interference prevent infection? Trends Microbiol 9, 424-428.

Sachse, S., Seidel, P., Gerlach, D., Günther, E., Rödel, J., Straube, E. \& Schmidt, K.-H. (2002). Superantigen-like gene(s) in human pathogenic Streptococcus dysgalactiae, subsp. equisimilis: genomic localisation of the gene encoding streptococcal pyrogenic exotoxin $\mathrm{G}$ $\left(\right.$ spe $\left.G^{d y s}\right)$. FEMS Immunol Med Microbiol 34, 159-167.

Saitou, N. \& Nei, M. (1987). The neighbor joining method: a new method for reconstructing phylogenetic trees. Mol Biol Evol 4, 406.

Smith-Vaughan, H., Byun, R., Nadkarni, M., Jacques, N. A., Hunter, N., Halpin, S., Morris, P. S. \& Leach, A. J. (2006). Measuring nasal bacterial load and its association with otitis media. BMC Ear Nose Throat Disord 6, 10 .

Stackebrandt, E. \& Goebel, B. M. (1994). Taxonomic note: a place for DNA-DNA reassociation and $16 \mathrm{~S}$ rRNA sequence analysis in the present species definition in bacteriology. Int J Syst Bacteriol 44, 846-849.

Stanley, J., Burnens, A. P., Linton, D., On, S. L. W., Costas, M. \& Owen, R. J. (1992). Campylobacter helveticus sp. nov., a new thermophilic species from domestic animals: characterization, and cloning of a species-specific DNA probe. J Gen Microbiol 138, 2293-2303.

Tamura, K., Dudley, J., Nei, M. \& Kumar, S. (2007). MEGA4: Molecular Evolutionary Genetics Analysis (MEGA) software version 4.0. Mol Biol Evol 24, 1596-1599.

Tannock, G. W. (1999). The bowel microflora: an important source of urinary tract pathogens. World J Urol 17, 339-344.

Thompson, J. D., Higgins, D. G. \& Gibson, T. J. (1994). CLUSTAL W: improving the sensitivity of progressive multiple sequence alignment through sequence weighting, position-specific gap penalties and weight matrix choice. Nucleic Acids Res 22, 4673-4680.

Tom-Petersen, A., Leser, T. D., Marsh, T. L. \& Nybroe, O. (2003). Effects of copper amendment on the bacterial community in agricultural soil analyzed by the T-RFLP technique. FEMS Microbiol Ecol 46, 53-62.

Tyndale-Briscoe, H. (2005). Life of Marsupials, 2nd edn. Collingwood: CSIRO Publishing.

Vela, A. I., Falsen, E., Simarro, I., Rollan, E., Collins, M. D., Domínguez, L. \& Fernandez-Garayzabal, J. F. (2006). Neonatal mortality in puppies due to bacteremia by Streptococcus dysgalactiae subsp. dysgalactiae. J Clin Microbiol 44, 666-668.

Weisburg, W. G., Barns, S. M., Pelletier, D. A. \& Lane, D. J. (1991). 16S ribosomal DNA amplification for phylogenetic study. J Bacteriol 173, 697-703.

Wells, J. E., Williams, K. B., Whitehead, T. R., Heuman, D. M. \& Hylemon, P. B. (2003). Development and application of a polymerase chain reaction assay for the detection and enumeration of bile acid $7 \alpha$-dehydroxylating bacteria in human feces. Clin Chim Acta 331, $127-134$.

Xu, J., Chiang, H. C., Bjursell, M. K. \& Gordon, J. I. (2004). Message from a human gut symbiont: sensitivity is a prerequisite for sharing. Trends Microbiol 12, 21-28.

Xu, J., Mahowald, M. A., Ley, R. E., Lozupone, C. A., Hamady, M., Martens, E. C., Henrissat, B., Coutinho, P. M., Minx, P. \& other authors (2007). Evolution of symbiotic bacteria in the distal human intestine. PLoS Biol 5, e156.

Yadav, M., Stanley, N. F. \& Waring, H. (1972). The microflora of the gut of the pouch-young and the pouch of a marsupial, Setonix brachyurus. J Gen Microbiol 70, 437-442.

Edited by: D. M. Gordon 